\title{
ARTIKELEN
}

\section{De aanpak van de COVID-19-epidemie: een juridische tussenbalans}

\author{
Prof. mr. J.C.J. Dute
}

\section{Inleiding}

Ter bestrijding van de COVID-19-epidemie heeft de overheid ingrijpende maatregelen genomen op een schaal zoals we niet eerder hebben meegemaakt. Niet alleen is de economie ongekend hard geraakt, ook de bevolking heeft zich heel wat moeten laten welgevallen. Ik wijs op de befaamde 'anderhalvemeterregel', de sluiting van restaurants, cafés, scholen, kinderopvang, et cetera, het verbod om contactberoepen uit te oefenen, het evenementenverbod, bezoekbeperkingen, en zo verder.

Dat de overheid een belangrijke taak heeft bij de bestrijding van infectieziekten in het algemeen en bij COVID-19 in het bijzonder staat niet ter discussie. Deze taakstelling vloeit rechtstreeks voort uit artikel 22 Grondwet en uit diverse internationale verdragen waarin het recht op gezondheid, en daarmee de plicht van de overheid de (volks)gezondheid te beschermen, is vastgelegd. Echter, uit taken - ook niet uit grondwettelijk en verdragsrechtelijk geborgde taken - vloeien geen bevoegdheden voort, in elk geval geen bevoegdheden waarmee vrijheden kunnen worden ingeperkt (meer in het bijzonder de bewegingsvrijheid, de privacy en de lichamelijke integriteit). Dat is de essentie van de rechtsstaat, die ook, of misschien wel juist, in moeilijke tijden bewaakt moet worden.

De voor de bestrijding van infectieziekten relevante bevoegdheden zijn samengebracht in de Wet publieke gezondheid (Wpg; de opvolger van de Infectieziektenwet). Dit wettelijke kader schoot blijkbaar tekort voor COVID-19, waarop de overheid haar toevlucht nam tot het (laten) uitvaardigen van noodverordeningen op basis van de Wet veiligheidsregio's (Wvr) en de Gemeentewet (Gemw). Inmiddels wordt gewerkt aan een meer solide wettelijke grondslag voor de noodbevoegdheden door toevoeging van een (tijdelijk) hoofdstuk aan de Wpg. Bij de afronding van dit artikel was de discussie daarover nog in volle gang.

De aanpak van COVID-19 (voorheen corona) roept een aantal vragen op. Was de Wpg inderdaad niet toereikend en, zo ja, hoe komt dat dan? Hoe moet worden aangekeken tegen de noodverordeningen? Biedt de uitbreiding van de Wpg met een tijdelijk hoofdstuk nu de oplossing voor de geconstateerde problemen?

Deze vragen staan in deze bijdrage centraal. Ik beperk mij daarbij tot het nationale niveau en laat de internationale aspecten (met name de rol van de WHO en de Europese Unie) verder rusten. Ook de veelbesproken maatregelen in verband met verzorgings- en ver-

* Jos Dute is emeritus-hoogleraar gezondheidsrecht, Radboud Universiteit Nijmegen. 
pleeghuizen, psychiatrische instellingen en instellingen voor mensen met een verstandelijke beperking blijven goeddeels buiten beschouwing. ${ }^{1}$

Het plan van behandeling is als volgt. In paragraaf 2 wordt de betekenis van de Wpg voor de bestrijding van de COVID-19-epidemie besproken. De belangrijkste maatregelen in dat kader zijn echter neergelegd in de 25 noodverordeningen; daarop wordt ingegaan in paragraaf 3. Het wetsvoorstel, dat een einde moet maken aan de noodverordeningen, wordt besproken in paragraaf 4. Dan volgt een nadere beschouwing (paragraaf 5) en een conclusie (paragraaf 6). De ontwikkelingen gaan snel. Deze tekst is afgesloten op 22 september 2020, aan de vooravond van de tweede golf.

\section{Wet publieke gezondheid}

\subsection{Inleiding}

Het wettelijke instrumentarium voor de bestrijding van infectieziekten is, zoals gezegd, neergelegd in de Wet publieke gezondheid (Wpg) uit 2008. Voor zover hier relevant regelt de wet drie onderwerpen: een meldingsplicht voor artsen en virologische laboratoria, een aantal onderzoeks- en bestrijdingsmaatregelen, en een besluitvormingsstructuur. In verband met een en ander worden infectieziekten in drie groepen ingedeeld: A-, B- en Cziekten. ${ }^{2}$ De Wpg zelf geeft aan welke ziekten in welke categorie vallen. A-ziekten vormen de zwaarste categorie. COVID-19 (in de wet het novel coronavirus (2019-nCoV) genoemd) is sinds 28 januari 2020 als zodanig aangemerkt, dit op grond van de (ministeriële) Regeling 2019-nCoV. ${ }^{3}$ Bij spoed is een dergelijke regeling mogelijk op grond van artikel 20 Wpg. ${ }^{4}$ Wel dient dan binnen acht weken een voorstel tot incorporatie van de regeling in de Wpg naar de Tweede Kamer te worden gestuurd. Dat is gebeurd op 20 februari $2020 .{ }^{5}$ Zolang de parlementaire behandeling loopt blijft de regeling van kracht. Een termijn is daar niet aan verbonden. ${ }^{6}$

In het oog moet worden gehouden dat de Wpg geen blauwdruk van de infectieziektebestrijding geeft. De wet regelt alleen de verplichtingen die de overheid in dat verband kan opleggen. Die verplichtingen vormen het sluitstuk van het overheidsoptreden tegen infectieziekten, en niet de kern. ${ }^{7}$ De gedachte is dat ook zonder het opleggen van allerhande verplichtingen infectieziekten kunnen worden bestreden, omdat de bevolking de noodzaak van de maatregelen zal inzien. Zo is deelname aan een van de meest succesvolle maat-

1 Zie daarover T.P. Widdershoven, 'Coronamaatregelen in de ggz: zorgen over rechtmatigheid en rechtsbescherming', TvGR 2020, p. 251-257.

2 B-ziekten worden nog onderverdeeld in B1 en B2, maar dat is hier niet relevant.

3 De regeling is bekend gemaakt door plaatsing op de internetsite van het Ministerie van VWS en onmiddellijk na bekendmaking in werking getreden, hetgeen wordt mogelijk gemaakt door lid 5 van art. $20 \mathrm{Wpg}$. De regeling is verder op 31 januari gepubliceerd in de Staatscourant (Stcrt. 2020, 6800).

4 In het verleden is een dergelijke regeling ook uitgevaardigd voor de Mexicaanse griep.

5 Wijziging van de Wet publieke gezondheid tot incorporatie van de Regeling 2019-nCoV, Kamerstukken II 2019/20, 35401.

6 Om onduidelijke redenen ligt de behandeling van dit op 24 februari 2020 ingediende wetsvoorstel al sinds eind maart 2020 stil.

7 Voor het meldingssysteem ligt dit enigszins anders. 
regelen tegen infectieziekten, het Rijksvaccinatieprogramma, nooit verplicht gesteld. ${ }^{8}$ Welke consequenties heeft nu de toepasselijkheid van de Wpg voor de bestrijding van COVID-19? Hieronder loop ik de relevante onderdelen van de wet na.

\subsection{Surveillance}

Cruciaal bij de bestrijding van infectieziekten, dus ook bij die van COVID-19, is dat de overheid de verspreiding, de impact (mortaliteit en morbiditeit) en de verdere ontwikkelingen ter zake van het virus zo nauwkeurig mogelijk in beeld heeft. ${ }^{9}$ Dit wordt surveillance genoemd. Een centrale rol is hierbij weggelegd voor het RIVM, dat tot de persoon herleidbare gezondheidsgegevens mag verwerken, mits daarbij pseudonimisering (codering) is toegepast (art. 6c lid 2 en $3 \mathrm{Wpg}$ ). De wettelijke, nominatieve meldingsplicht voor artsen en onderzoekslaboratoria vormt binnen het geheel van surveillancesystemen een belangrijke schakel. Overigens zijn niet voor alle surveillancesystemen persoonsgegevens nodig (denk bijvoorbeeld aan het rioolonderzoek).

Wat betreft de wettelijke meldingsplicht: door de aanwijzing als A-ziekte is de (behandelend) arts verplicht om het vermoeden dan wel de vaststelling van de ziekte COVID-19 (tezamen met de personalia van de patiënt) 'onverwijld' te melden bij de GGD (art. 22 lid 1 Wpg). Virologische laboratoria hebben een vergelijkbare meldingsplicht met betrekking tot positieve testuitslagen (art. $25 \mathrm{Wpg}$ ). Omdat een COVID-19-infectie in de meeste gevallen een mild beloop heeft, is het niet zinvol om reeds bij een vermoeden tot melding over te gaan. Daarom geeft de COVID-19-richtlijn van het RIVM aan dat 'tot nader order alleen bevestigde patiënten gemeld dienen te worden aan de GGD. ${ }^{10}$ Melding van bevestigde patiënten is met name van belang, omdat deze het startpunt vormen van het bron- en contactonderzoek. Daarom dient deze melding nominatief te zijn.

\subsection{Bron- en contactonderzoek}

Volgens de COVID-19-richtlijn van het RIVM voert de GGD bij een bevestigde patiënt bron- en contactonderzoek uit. Welke betekenis heeft de Wpg in dit verband? Bron- en contactonderzoek is als taakstelling neergelegd in artikel 6 lid 1 sub c Wpg, maar zoals gezegd: uit taken vloeien geen bevoegdheden voort. Op grond van artikel $30 \mathrm{Wpg}$ is het, met tussenkomst van de voorzitter van de veiligheidsregio (verder: de voorzitter), mogelijk om medische informatie op te vragen bij de behandelend arts(en). In de praktijk zal de GGD zich zelfstandig met de arts in verbinding stellen - daarvoor moet dan wel mandaat zijn verleend door de voorzitter. De voor bron- en contactonderzoek benodigde informatie wordt overigens in eerste instantie rechtstreeks bij de patiënt (in het jargon: de 'index') verkregen of, als dit niet mogelijk is, via een contactpersoon.

Een verplichting tot het ondergaan van een test kan niet worden opgelegd, noch aan de index noch aan diens huisgenoten en verdere contacten. Verplicht testen is op grond van

$8 \mathrm{Al}$ is daar wel met enige regelmaat discussie over, in verband met polio en meer recent mazelen. Zie ook J. Legemaate, 'Vaccinatie van jonge kinderen: vrijwillig of (soms) toch verplicht?', TvGR 2020, p. 258-265.

9 Een actueel overzicht biedt het dashboard corona, https://coronadashboard.rijksoverheid.nl

10 https://lci.rivm.nl/richtlijnen/covid-19. Strikt genomen dient een dergelijke aanpassing van de meldingsverplichting bij ministeriële regeling te worden vastgesteld. Art. 6c lid $1 \mathrm{Wpg}$, waarin het RIVM wordt opgedragen namens de minister werkzaamheden te verrichten bij de bestrijding van infectie, kan mijns inziens niet als delegatiebepaling worden gezien. 
de wet alleen toegestaan bij iemand die ter isolatie is opgenomen. Bovendien is daarvoor een rechterlijke machtiging nodig (art. $31 \mathrm{Wpg}$ ).

Al met al heeft de Wpg, afgezien van de verplichte melding, geen betekenis voor bron- en contactonderzoek. Dergelijk onderzoek kan alleen plaatsvinden op basis van instemming c.q. medewerking van de betrokkene. ${ }^{11}$

\subsection{Quarantaine, isolatie en verdere bestrijdingsmaatregelen}

De aanwijzing van COVID-19 als A-ziekte maakt een aantal ingrijpende maatregelen mogelijk. De belangrijkste zijn isolatie (art. 31 e.v. Wpg), quarantaine en medisch toezicht (art. 35 e.v. Wpg), het verbod om beroeps- of bedrijfsmatig werkzaamheden te verrichten (art. $38 \mathrm{Wpg}$; werkverbod) en een aantal maatregelen in verband met gebouwen, terreinen, goederen en vervoermiddelen (art. $47 \mathrm{Wpg}$ ).

Isolatie impliceert opneming in een speciaal door de minister aangewezen ziekenhuis. Deze vrijheidsontneming kan alleen worden opgelegd door de voorzitter van de veiligheidsregio (niet door de burgemeester) en is, met het oog op artikel 5 EVRM, aan strakke materiële en procedurele waarborgen gebonden. Nadat de voorzitter de beschikking heeft afgegeven, vordert de officier van justitie een machtiging tot voortzetting van de isolatie, waarover de rechter binnen drie dagen dient te beslissen.

Voor quarantaine en medisch toezicht, twee maatregelen die tegelijk worden opgelegd, geldt eenzelfde procedure, alleen kunnen zij ook thuis worden uitgevoerd. Een belangrijk verschil met isolatie is dat isolatie alleen bij een bevestigde patiënt kan worden toegepast, terwijl quarantaine reeds kan worden opgelegd aan 'een dusdanig contact met een lijder of een vermoedelijke lijder aan [COVID-19], dat deze persoon mogelijk met dezelfde ziekte is geïnfecteerd'. De bedoeling is dat wordt gekeken of de betrokkene ziekteverschijnselen ontwikkelt of dat anderszins komt vast te staan dat deze al dan niet met het virus is besmet (bijvoorbeeld door een - vrijwillige - test). Zo ja, dan komt isolatie in beeld.

Medisch toezicht tijdens quarantaine houdt niet de bevoegdheid tot testen in. ${ }^{12}$ Verder moet goed in het oog worden gehouden dat quarantaine alleen bij een vermoeden van besmetting aan de orde kan zijn en niet meer bij een positieve test (immers: dan staat de besmetting vast). Dan kan alleen nog isolatie worden opgelegd.

Isolatie en quarantaine, zoals hier bedoeld, dus als verplichting, zijn bij COVID-19 overigens (nog) niet toegepast. Positief geteste patiënten krijgen het advies om thuis te blijven en wie met een patiënt in contact is geweest wordt gevraagd zijn/haar gezondheid tien dagen (voorheen twee weken) goed in de gaten te houden en thuis te werken, dit alles dus op basis van vrijwilligheid. Dat kan ook moeilijk anders. Het op enige schaal toepassen van gedwongen isolatie leidt al snel tot capaciteitsproblemen in ziekenhuizen. Verplichte thuisquarantaine zal bij grote aantallen ook niet eenvoudig zijn. Vergelijkbare problemen doemen op bij een grootschalige toepassing van het wettelijke werkverbod. Daarbij moet worden bedacht dat het hier niet gaat om algemene ge- en verboden, zoals een verbod

11 Gedetailleerde meldingsverplichtingen in verband met COVID-19 zijn er voorts voor het internationale scheep- en luchtvaartverkeer. Die meldingsverplichtingen en de specifieke bestrijdingsmaatregelen die in verband met het scheep- en luchtvaartverkeer kunnen worden genomen, laat ik hier verder rusten.

12 Gelet op de wijze waarop het sputum wordt afgenomen moet de test mijns inziens worden beschouwd als een onderzoek in het lichaam en niet als een onderzoek aan het lichaam. 
bepaalde beroepen of werkzaamheden uit te oefenen, maar om maatregelen die bij individuele beschikking worden opgelegd.

Sluiting van gebouwen of terreinen, ontsmetting, het verbod om gebruik te maken van vervoermiddelen en vergelijkbare maatregelen die de burgemeester of de voorzitter op grond van artikel $47 \mathrm{Wpg}$ kan nemen en die kunnen worden versterkt met een last onder bestuursdwang, zijn bij de bestrijding van COVID-19 wel bruikbaar. Maar voor zover ik kan waarnemen wordt deze wettelijke grondslag niet gebruikt, maar worden de vereiste maatregelen genomen op grond van de - hierna te bespreken - noodverordeningen.

Alles bijeengenomen biedt de Wpg maar weinig soelaas voor de aanpak van COVID-19. De wet kent niet de vele, uiteenlopende maatregelen die juist bij COVID-19 nodig zijn gebleken, zoals afstand houden, samenkomstverboden, beperkingen van bezoekrecht, gebieds- en locatieverboden, beperkingen voor restaurants en cafés, enzovoort. De maatregelen waarin de wet wel voorziet, worden niet toegepast, vermoedelijk vanwege hun individuele gerichtheid en de als omslachtig ervaren procedure.

\subsection{Besluitvormingsstructuur}

De Wpg regelt niet alleen (enkele aspecten van) de surveillance en een aantal onderzoeksen bestrijdingsmaatregelen, maar kent ook een besluitvormingsstructuur. Die is wel van grote betekenis geweest voor de aanpak van COVID-19. In de Wpg is gekozen voor een decentrale uitvoeringsstructuur, die bij een A-ziekte een meer centrale invulling krijgt. De voorzitters van de veiligheidsregio's nemen dan de plaats in van de burgemeesters (art. 6 lid $4 \mathrm{Wpg}$ ) en zij komen op hun beurt onder leiding te staan van de Minister van VWS (art. $7 \mathrm{Wpg}){ }^{13}$

In dat kader overlegt de minister met de betrokken bestuursgremia, zoals de voorzitters van de veiligheidsregio's (Veiligheidsberaad), ${ }^{14}$ de VNG, enzovoorts (het zogenoemd bestuurlijk afstemmingsoverleg; BAO). De inbreng van deskundigen verloopt via het outbreak management team (OMT), onder voorzitterschap van de directeur van het Centrum Infectieziekten van het RIVM (Jaap van Dissel). Het OMT, dat anders dan het BAO geen wettelijke grondslag heeft, kent een wisselende samenstelling; er zijn een aantal vaste leden, terwijl daarnaast andere personen kunnen worden uitgenodigd op grond van hun expertise. ${ }^{15}$ Zij nemen deel op persoonlijke titel. Onafhankelijkheid staat daarbij voorop. Het BAO toetst het advies van het OMT op bestuurlijke haalbaarheid en uitvoerbaarheid. De besluitvorming is verder opgeschaald door toepassing te geven aan het Instellingsbesluit Ministeriële Commissie Crisisbeheersing $2016^{16}$ en het Nationaal Handboek Crisisbesluitvorming. De Minister van Justitie en Veiligheid (JenV) is de coördinerend minister voor crisisbeheersing, die daarbij wordt ondersteund door de Nationaal Coördinator Terrorismebestrijding en Veiligheid. De Ministeriële Commissie Crisisbeheersing (MCCb),

13 Tegelijk zijn in het kader van de Wvr de veiligheidsregio's opgeschaald naar het zogenoemde GRIP-4niveau. Zie over het verloop hiervan bij COVID-19: Instituut Fysieke Veiligheid, De veiligheidsregio's in de eerste weken van de coronacrisis, Arnhem: IFV 2020 (www.ifv.nl/kennisplein/Documents/20200501-IFV-Deveiligheidsregios-in-de-eerste-weken-van-de-coronacrisis.pdf).

14 Zie over het Veiligheidsberaad www.veiligheidsberaad.nl/covid-19/.

15 Zie voor de samenstelling van het COVID-19 OMT: www.rivm.nl/coronavirus-covid-19/omt.

16 Stcrt. 2016, 48258. 
waaraan verschillende bewindslieden deelnemen, staat onder voorzitterschap van de premier en neemt de uiteindelijke beslissingen over de aanpak van de epidemie.

Zo bezien oogt de besluitvormingsstructuur betrekkelijk ingewikkeld. Naast de crisisstructuur, met aan de top de MCCb en als coördinator de Minister van JenV, staat de besluitvormingslijn van de Wpg, met aan de top de Minister van VWS. De Minister van VWS heeft op grond van de Wpg een eigen verantwoordelijkheid, maar voegt zich uiteraard naar de besluitvorming binnen de $\mathrm{MCCb}$. De besluitvormingsstructuur als geheel waarborgt, in al zijn ingewikkeldheid, intussen wel drie belangrijke aspecten: dat er overleg is tussen het centrale en decentrale overheidsniveau, dat deskundigen een duidelijke inbreng hebben en dat de beslissingen over de te volgen koers bij de bestrijding uiteindelijk politiek zijn. Opmerking verdient nog dat de gezagsstructuur als voorzien in de Wet buitengewone bevoegdheden burgerlijk gezag terzijde is gelaten.

\section{Noodverordeningen}

De Wpg kent niet de mogelijkheid om bij AMvB of bij ministeriële regeling nieuwe onderzoeks- en bestrijdingsmaatregelen in het leven te roepen. De wet biedt evenmin een wettelijke grondslag voor de gemeenteraden, en daarmee dus ook niet voor de veiligheidsregio's, om nadere regels te stellen voor de bestrijding van infectieziekten. Dit is een bewuste keuze van de wetgever geweest, al geeft de parlementaire toelichting daarvoor geen specifieke reden. ${ }^{17}$

Wel biedt de Gemeentewet in artikel 176 de burgemeester de mogelijkheid om ter handhaving van de openbare orde of ter beperking van gevaar algemeen verbindende voorschriften vast te stellen (noodverordeningen). In gemeente-overstijgende situaties gaat deze bevoegdheid ex artikel 39 Wvr over op de voorzitter van de veiligheidsregio. De minister heeft de voorzitters van de 25 veiligheidsregio's verschillende aanwijzingen gegeven tot het vaststellen van noodverordeningen aan de hand van een bepaald model, ${ }^{18}$ dit op grond van artikel $7 \mathrm{Wpg}$. Dit mag gerust een juridische vondst worden genoemd. De bevoegdheid ex artikel $7 \mathrm{Wpg}$ is, naar het mij voorkomt, bedoeld geweest om binnen het kader van de Wpg te worden toegepast. In elk geval kan het toch niet de bedoeling zijn geweest dat deze bevoegdheid wordt gebruikt om, naast en met voorbijgaan aan de Wpg, een geheel nieuw en omvangrijk wettelijk stramien voor de bestrijding van een onder de Wpg vallende infectieziekte te creëren.

Wat hier verder van zij, de in de noodverordeningen opgenomen maatregelen zijn bekend: samenkomstverboden, verbod op het niet houden van een veilige afstand, verbod zich te bevinden in aangewezen gebieden en locaties, verbod op bepaalde onderwijsactiviteiten, verbod op het bezoeken van verpleeg- en verzorgingshuizen, enzovoort. Aanwijzingen van bevoegde ambtenaren dienen 'stipt en onmiddellijk opgevolgd te worden' (art. 4.1) en

17 Met de komst van de Infectieziektenwet, de voorganger van de Wpg, is de aanvullende verordeningsbevoegdheid van de gemeenten, die voorheen wel bestond, vervallen, Kamerstukken II 1996/97, 25336, nr. 3, p. 5.

18 De laatste versie dateert van 15 juli 2020. De bedoeling van het model is het bevorderen van uniformiteit. Niettemin kennen de noodverordeningen onderling kleine variaties. Zie voor een overzicht hiervan www.eerstekamer.nl/overig/20200626/memo_veiligheidsberaad_van_4_juni_2/meta. De totstandkoming van de noodverordeningen kende wat aanloopperikelen, zie daarvoor Bart Roozendaal \& Stefan van de Sande, 'COVID-19 in het publiekrecht - een overzicht', NJB 2020, 14, p. 938-947. 
overtreding van de voorschriften is strafbaar. Probleem is dat de noodverordeningen zich bewegen op het terrein van de grondrechten en dat mag niet van artikel 176 Gemw. Immers, daarin staat dat alleen 'van andere dan bij de Grondwet gestelde voorschriften kan worden afgeweken'. Anders gezegd: voor grondrechtenbeperkende maatregelen is een formele wettelijke grondslag nodig.

Uiteraard is altijd discussie mogelijk over de vraag of en wanneer een maatregel precies inbreuk maakt op een grondrecht. Is het verbod om gezamenlijk te zingen of te schreeuwen een grondrechtenbeperking? Ik denk het wel, en de opstellers van de noodverordeningen kennelijk ook, want voor kerkdiensten wordt onmiddellijk een uitzondering gemaakt. Is het verplicht dragen van een mondkapje een inbreuk op de persoonlijke levenssfeer? Dat kan toch moeilijk worden ontkend. Dat verandert niet door te zeggen dat in het licht van de pandemie het dragen van een mondkapje een geringe beperking is van de persoonlijke levenssfeer'. ${ }^{19}$ Ook het bestempelen van de mondkapjesplicht als '(gedrags)experiment', zoals burgemeester Aboutaleb van Rotterdam deed, verandert mijns inziens niets aan de noodzaak van een deugdelijke wettelijke grondslag. Volgens de Voorzieningenrechter is de mondkapjesplicht inderdaad een inbreuk op artikel 10 Grondwet, zij het 'een relatief gering inbreuk', en onvoldoende om de noodverordening onmiskenbaar onverbindend te maken. ${ }^{20}$

Aan de noodverordeningen zitten dus de nodige haken en ogen. Iets anders is welke gevolgen aan deze constatering moeten worden verbonden. Ik kom daar in paragraaf 5 nog op terug. Hier merk ik nog op dat we met COVID-19 weliswaar in lastige tijden zijn beland, maar dat (nog) geen sprake is van een (beperkte of algemene) noodtoestand als bedoeld in de Coördinatiewet uitzonderingstoestanden. In enkele andere landen is eerder wel de noodtoestand uitgeroepen, zoals in Frankrijk, Spanje en Italië.

\section{Nieuwe wettelijke grondslag in de steigers}

Het besef dat het juridische bouwwerk van de noodverordeningen wankel is, wordt inmiddels breed gedeeld. Behalve de grondrechtenproblematiek zijn algemene noodverordeningen niet bedoeld om voor langere tijd te worden ingezet. Noodverordeningen missen verder een rechtstreekse democratische legitimatie. Ook de handhaving is problematisch. ${ }^{21}$ Een stevigere juridische basis is derhalve nodig, aldus ook de Raad van State. ${ }^{22}$ Daarom is op 13 juli 2020 een wetsvoorstel ingediend om een beter fundament onder de COVID-19-maatregelen te leggen. ${ }^{23}$

Het wetsvoorstel voegt aan de Wpg een nieuw hoofdstuk Va toe met als opschrift 'Tijdelijke bepalingen bestrijding epidemie COVID-19'. Zoals het opschrift al aangeeft gaat

19 Hoogleraar staatsrecht Paul Bovend'eert in de Volkskrant van 3 augustus 2020.

20 Vzr. Rb. Amsterdam 19 augustus 2020, ECLI:NL:RBAMS:2020:4057. De procedure tot buitenwerkingstelling van de noodverordening was aangespannen door (onder meer) de Stichting Viruswaarheid. Bedacht moet worden dat in dit kader een terughoudende toetsing wordt toegepast.

21 Zie hierover: Roozendaal \& Van de Sande 2020, m.n. p. 946-947.

22 Voorlichting over de grondwettelijke aspecten van (voor)genomen crisismaatregelen, 25 mei 2020 (W04.20.0139/I/Vo), § 11, uitgebracht naar aanleiding van de motie Van der Staaij en Jetten, Kamerstukken II 2019/20, 25295 , nr. 234.

23 Kamerstukken II 2019/20, 35526. 
het om een tijdelijke regeling. Zij vervalt in beginsel na zes maanden, maar kan telkens met drie maanden worden verlengd (art. VIII). De meeste maatregelen, zoals we die nu kennen van de noodverordeningen, komen met wat aanpassingen en uitzonderingen in de regeling terug. Daarbij is de structuur steeds zo dat de minister regels kan stellen ten aanzien van de verschillende onderwerpen, zoals groepsvorming, openstelling publieke plaatsen, evenementen, hygiënemaatregelen, beschermingsmiddelen, uitoefening van contactberoepen, personenvervoer, onderwijsactiviteiten, kinderopvang, enzovoorts. Het parlement krijgt vervolgens een week de tijd zich over de ministeriële regeling uit te laten (voorhangprocedure). Alleen de veilige afstand wordt bij AMvB geregeld.

De minister kan van zijn bevoegdheden alleen gebruikmaken voor zover dat noodzakelijk en proportioneel is (art. 58b lid 2). Het huisrecht wordt gerespecteerd (dus geen maatregelen 'achter de voordeur'), behalve bij zorglocaties. Zorgaanbieders en zorglocaties moeten het mogelijk maken dat bezoekers zich aan de regels houden, terwijl voorts de minister voorwaarden en beperkingen aan bezoek kan stellen (art. 58o).

Sluitstuk van de regeling is de vangnetbepaling (art. 58s). Als de in de wet voorziene maatregelen niet toereikend zijn, kan de minister ook andere maatregelen nemen. En mocht dat te lang duren, dan kunnen de noodverordeningen weer worden ingezet.

De nu voorgestelde regeling ${ }^{24}$ is niet alleen van toepassing als een epidemie van COVID-19 heerst, maar ook bij een 'directe dreiging' daarvan (art. 58b). Omdat zo'n dreiging er altijd wel zal zijn, mag worden verwacht dat de als tijdelijk bedoelde regeling telkens zal worden verlengd, net zo lang totdat er een adequaat vaccin beschikbaar is.

De noodverordeningen verdwijnen - die zijn door deze wettelijke regeling overbodig geworden. Maar, zoals gezien, bij spoed kan toch weer naar het middel van de noodverordening worden gegrepen. Ik kan me echter niet voorstellen dat een noodverordening sneller tot stand kan komen dan een ministeriële regeling. Deze mogelijkheid kan dus beter worden geschrapt. Daar komt nog bij dat de wettelijke mogelijkheid die de Gemeentewet / Wet veiligheidsregio's biedt om noodverordeningen vast te stellen, natuurlijk gewoon blijft bestaan. Het risico daarvan is, en we zien dit in de praktijk eigenlijk al, dat er meerdere kapiteins op één schip zijn. De invoering van de mondkapjesplicht in Amsterdam en Rotterdam is daarvan een voorbeeld.

In nieuwe maatregelen voorziet de regeling niet of nauwelijks. Dat was ook niet de bedoeling. ${ }^{25}$ Wat opvalt, zeker nu de testbereidheid van de bevolking te wensen overlaat, is dat verplicht testen geen deel uitmaakt van het pakket aan maatregelen. Kennelijk vindt het kabinet verplicht testen een te vergaande inbreuk op de privacy, althans om hiervoor een wettelijke grondslag voor de minister te creëren. Naar mijn oordeel terecht - vergelijk op dit punt ook de beperkte ruimte die artikel 31 lid 4 Wpg biedt voor verplicht testen en de strenge waarborgen waarmee deze maatregel is omgeven. Waarom de veilige afstand van anderhalve meter niet gewoon in de wet is vastgelegd, maar bij AMvB wordt geregeld, ontgaat me.

De minister heeft, meer nog dan voorheen, de wettelijke positie van spil en regisseur gekregen, ook voor de gedifferentieerde toepassing van de maatregelen op regionaal en lokaal niveau. Ook zijn specifieke bevoegdheden weer belegd bij de burgemeester (zoals in de rest

25 Zie ook Kamerstukken II 2019/20, 35526, nr. 3, p. 4 (MvT). 
van de Wpg), al blijft opschaling naar de voorzitter van de veiligheidsregio steeds mogelijk (art. 58d).

\section{Nadere beschouwing}

In deze epidemie is het arsenaal aan maatregelen waarin de Wpg voorziet, van betrekkelijke waarde gebleken. In feite is daar, in de vorm van de 25 noodverordeningen, een geheel nieuw regelingskader naast gezet. Heeft de wetgever zich destijds geen voorstelling kunnen maken van een epidemie van het kaliber COVID-19, zodat de wet daarop ook niet kon worden ingericht? Mogelijk, maar wel moet worden bedacht dat een grootschalige lockdown (ook een 'intelligente' lockdown) in feite een weinig verfijnde manier van infectieziektebestrijding is. Een grootschalige lockdown is onaantrekkelijk vanwege de desastreuze en ontwrichtende werking die ervan uitgaat op maatschappij, handel, economie en verkeer, zoals ook wel is gebleken. Maar bij COVID-19 is deze aanpak toch weer uit de kast gehaald.

Opvallend is de belangrijke rol die (de voorzitters van) de veiligheidsregio's hebben gekregen. Langs de weg van de Wvr oefenen zij niet alleen uitvoerende bevoegdheden uit, zoals voorzien in de Wpg, maar treden zij ook regelstellend op. Bovendien zijn de burgemeesters daarmee buitenspel komen te staan. ${ }^{26}$

Het is duidelijk dat de noodverordeningen met de daarin vervatte grondrechtenbeperkingen zacht gezegd niet de schoonheidsprijs verdienen. Ook in democratisch opzicht schieten zij tekort, nu over de noodverordeningen niet rechtstreeks verantwoording hoeft te worden afgelegd tegenover een vertegenwoordigend orgaan. Toch vond de Voorzieningenrechter in de door Stichting Viruswaarheid tegen de staat aangespannen procedure dat hier voor rechterlijk ingrijpen geen plaats was. ${ }^{27}$ Het is op zichzelf wel begrijpelijk dat de Voorzieningenrechter er weinig voor voelde het broze bouwwerk van de noodverordeningen omver te trekken. Een bestuurlijke chaos was anders het gevolg geweest, met alle consequenties van dien voor de aanpak van de epidemie. Helaas heeft de rechter de vraag naar de verenigbaarheid van de noodverordeningen met de Grondwet laten lopen. ${ }^{28}$

Met het voorgestelde nieuwe hoofdstuk in de Wpg komt (in principe) een einde aan de noodverordeningen. Dat is winst. Wat ervoor terugkomt is een machtigingswet, die alle ruimte biedt aan de minister, terwijl het parlement over zijn schouder meekijkt. De vraag is of de rol van het parlement niet moet worden versterkt, in die zin dat het parlement niet slechts (binnen een week) kan reageren, maar de regeling vooraf moet bekrachtigen, zoals

26 Met uitzondering natuurlijk van de burgemeesters die tevens voorzitter van een veiligheidsregio zijn, zoals de die van Amsterdam en Rotterdam.

27 Vzr. Rb. Den Haag 24 juli 2020, ECLI:NL:RBDHA:2020:6856. Maar zie de in noot 20 genoemde uitspraak van de Vzr. Rb. Amsterdam, die de mondkapjesplicht beschouwt als een relatief geringe inbreuk op art. 10 Grondwet, onvoldoende om de noodverordening onmiskenbaar onverbindend te achten. Ik wijs verder nog op Vzr. Rb. Den Haag 3 april 2020, ECLI:NL:RBDHA:2020:3013, waarin (tevergeefs) juist meer en strengere maatregelen (volledige lockdown) werden geëist.

28 De Voorzieningenrechter gaat alleen in op de vraag naar de verenigbaarheid met het EVRM, in welk kader voor grondrechtenbeperking geen wet in formele zin is vereist, zoals de Grondwet dat wel doet, maar een wet in materiële zin volstaat. 
bepleit door Voermans. ${ }^{29}$ Daar staat tegenover dat met een dergelijke bekrachtigingsregeling het gevaar dreigt dat de aanpak van de epidemie (verder) wordt gepolitiseerd, hetgeen ten koste kan gaan van de slagvaardigheid.

De voorgestelde wettelijke regeling kent een vervaltermijn. Zoals gezegd valt te verwachten dat het hoofdstuk pas vervalt op het moment dat er een doeltreffend vaccin beschikbaar is. Met het vervallen van de regeling zijn we wel weer terug bij af. Nagedacht zal moeten worden over een meer structurele bijstelling van de Wpg, want nieuwe (en misschien nog wel virulentere) virussen zullen zich blijven aandienen.

\section{Conclusie}

De Wpg is tijdens de COVID-19-epidemie maar beperkt bruikbaar gebleken en heeft daarmee haar waarborgfunctie ook niet goed kunnen vervullen. Met een spitsvondigheid, te weten de route van artikel $7 \mathrm{Wpg}$, heeft de minister de veiligheidsregio's opgedragen noodverordeningen vast te stellen en daarmee een geheel nieuw wettelijk kader opgetrokken voor de bestrijding van de epidemie. De noodverordeningen schieten in democratisch opzicht tekort en staan op gespannen voet met de Grondwet, zo al niet gezegd moet worden dat ze ermee in strijd zijn. Maar de rechter heeft dit tot nu toe door de vingers gezien. Met toevoeging van een nieuw, tijdelijk hoofdstuk aan de Wpg, in feite een machtigingswet die de minister de ruimte geeft tal van maatregelen te nemen met een korte voorhangprocedure voor het parlement, wil de minister de bezwaren ondervangen die aan de noodverordeningen kleven. De regeling laveert tussen slagvaardigheid en democratische controle. De balans die daartussen is gezocht is voor discussie vatbaar, maar mijns inziens wel verdedigbaar. Na afloop van de COVID-19-epidemie zal de Wpg nog eens goed tegen het licht moeten worden gehouden.

\section{Naschrift}

Ik zei het al in de inleiding: de ontwikkelingen gaan snel. $\mathrm{Na}$ afsluiting van dit artikel (op 22 september 2020) is duidelijk geworden dat de voorgestelde wijziging van de Wpg (in de volksmond: 'coronawet' of 'spoedwet') verder zal worden aangepast. Bovenstaande tekst is daarom niet meer geheel up-to-date. Naar het zich laat aanzien - op het moment van schrijven was de precieze wettelijke vormgeving van alle aanpassingen nog niet beschikbaar - zal de initiële geldingsduur van zes maanden worden teruggebracht naar drie maanden. De inbreng van het parlement zal worden versterkt in die zin dat de Tweede Kamer met de ministeriële regeling moet instemmen, voordat deze van kracht wordt (van een machtigingswet is dus niet langer sprake). Bij spoed treedt de ministeriële regeling onmiddellijk in werking, maar kan de Tweede Kamer haar binnen een week alsnog verwerpen. De burgemeester krijgt een grotere rol toebedeeld, ten koste van die van de voorzitter van de veiligheidsregio. De bestrijding van COVID-19 mag in de toekomst niet meer via noodverordeningen plaatsvinden (ook de burgemeester kan die niet meer uitvaardigen). Daarnaast wordt de strafbaarstelling aangepast (lagere boete, geen strafblad) en is een bezoekverbod voor verpleeghuizen en zorglocaties niet langer mogelijk. 